\title{
OPTIMASI CHANNEL XRD ARL9900 SEBAGAI METODE ALTERNATIF UNTUK ANALISA LIMESTONE DALAM SEMEN
}

\author{
Sugeng Mulyono'; Dzakiyatul Azizah²; Hafit Setiyabudi ${ }^{3}$ \\ ${ }^{1}$ Teknik Mesin, Politeknik Negeri Jakarta \\ ${ }^{2}$ Teknik Mesin, Konsentrasi Rekayasa Industri, Politeknik Negeri Jakarta, \\ ${ }^{3}$ Laboratorium Kimia, PT. Holcim Indonesia Tbk. \\ e-mail : sugeng.mulyono@mesin.pnj.ac.id
}

\begin{abstract}
Loss On Ignition (LOI) is one of the parameters of cement testing analysis to determine the percentage of substance lost from the sample in a certain time and temperature. LOI cement is mainly caused by loss of water and carbon dioxide content in $\mathrm{CaCO} 3$ (Calcite) carbonate compounds in Limestone at $950^{\circ} \mathrm{C}$. .

From the results of this test can be predicted Limestone filler content in cement. Conventional methode of LOI is less efficient because need a relatively long time of about 2 hours and even more. The impact of this problem may lead to delays in production control decision making.

The purpose of this research is to make LOI testing more efficient and also produced Calcite Curve as a secondary method for LOI testing. At PT Holcim Indonesia Laboratory there is Xray Fluorescence (XRF) instrument equipped with Xray Diffraction (XRD) channel which can be used for LOI analysis so that the testing process can be faster.

The implementation method is made by making a correlation between Calcite with LOI and making Calcite calibration curve in channel XRD then sample tested.

From the results of this research trials obtained LOI test results with XRD 7 minutes 34 seconds with accuration percentage is 44,67\% and testing with wet method obtained 2 hours 27 minutes 57 seconds. From these results it can be concluded that LOI testing using XRD is 2 hours 20 minutes 23 seconds faster than wet method but not yet accurate. This method is still in the evaluation stage, it is necessary to repair to minimize percent error so that the test result more efficient and accurate, that is by modification of sample preparation or modification of Xray calibration parameter.
\end{abstract}

Keywords: LOI, Calcite, Calibration curve, XRF, XRD

\begin{abstract}
ABSTRAK
Loss On Ignition (LOI) atau kandungan hilang pijar adalah salah satu parameter analisis pengujian semen untuk mengetahui persentase kandungan zat yang hilang dari sampel dalam waktu dan suhu tertentu. LOI semen terutama disebabkan oleh hilangnya kandungan air dan karbondioksida dalam senyawa karbonat $\mathrm{CaCO}_{3}$ (Calcite) dalam Limestone pada suhu $950^{\circ} \mathrm{C}$. Berdasarkan hasil pengujian ini dapat diprediksi kadar Limestone filler dalam semen, karena bisa dihitung dari kandungan Calcite yang terdapat dalam Limestone filler.

Metode konvensional pengujian LOI kurang efisien karena memerlukan waktu yang relatif lama yaitu sekitar 2 jam bahkan lebih. Dampak dari masalah ini bisa menyebabkan terjadinya keterlambatan dalam pengambilan keputusan kontrol produksi.

Tujuan penelitian ini yaitu untuk membuat pengujian LOI menjadi lebih efisien dan juga dihasilkan Kurva Calcite sebagai metode alternatif untuk pengujian LOI. Di Laboratorium PT Holcim Indonesia terdapat instrument Xray Fluorescence (XRF) yang dilengkapi dengan channel Xray Diffraction (XRD) yang bisa dimanfaatkan untuk analisa LOI sehingga proses pengujiannya bisa lebih cepat.

Metode pelaksanaan dibuat dengan cara membuat korelasi antara Calcite dengan LOI dan pembuatan kurva kalibrasi Calcite di channel XRD lalu dilakukan uji coba sampel.

Berdasarkan hasil uji coba penelitian ini didapatkan hasil pengujian LOI dengan XRD 7 menit 34 detik dengan tingkat akurasi sebesar 44,67\%, dan pengujian dengan metode wet didapatkan 2 jam 27 menit 57 detik. Dari hasil tersebut dapat disimpulkan bahwa pengujian LOI menggunakan XRD lebih cepat 2 jam 20 menit 23 detik dibandingkan dengan metode wet tetapi belum akurat. Metode ini masih dalam tahap evaluasi, diperlukan adanya perbaikan untuk meminimalisir persen error supaya hasil pengujian lebih efisien dan akurat, yaitu dengan cara modifikasi preparasi sampel atau modifikasi parameter kalibrasi Xray.
\end{abstract}

Kata Kunci : LOI, Calcite, Kurva kalibrasi, XRF, XRD

\section{PENDAHULUAN}

Pengujian dalam semen terdapat beberapa parameter, salah satunya yaitu LOI (Loss On Ignition) atau kandungan hilang pijar yang terdapat dalam semen. Kandungan yang hilang ketika pemijaran yaitu kadar air yang terikat dan juga karbon dioksida $\left(\mathrm{CO}_{2}\right)$ yang terdapat dalam karbonat dalam semen [1] . Analisa LOI dalam semen ini salah satunya 
bertujuan sebagai parameter acuan yang dipakai untuk pengecekan proporsi Limestone filler, karena kadar karbonat tertinggi ada dalam Limestone filler. Sehingga dari nilai LOI sudah bisa diprediksi berapa persentase Limestone filler yang dipakai dalam semen tersebut.

Pengujian LOI ini biasanya rutin dilakukan untuk semua tipe semen dengan metode konvensional, yaitu wet analysis, yaitu dengan cara dipijarkan suatu sampel semen yang sudah ditimbang terlebih dahulu didalam tanur bersuhu $950^{\circ} \mathrm{C}$ selama \pm 1 jam, lalu didinginkan kemudian ditimbang dan diulangi lagi sampai bobot tetap. Waktu pengerjaannya yang relatif lama juga memiliki faktor error yang cukup banyak diantaranya kebersihan cawan, akurasi neraca, optimasi panas furnace, human error dan lain sebagainya, menjadikan metode ini kurang efisien. Saat ini, industri semen mulai banyak meninggalkan metode ini karena sudah kuno dan mulai beralih ke metode instrument.

Terdapat beberapa metode untuk mengatasi hal itu seperti menggunakan alat instrument yaitu thermogravimetric analysis, tetapi biayanya cukup mahal, sehingga penelitian ini mencoba memanfaatkan instrument yang sudah ada yaitu Xray Flourescence (XRF) yang sudah dilengkapi Xray Diffraction (XRD) channel yang membaca kristal. XRD ini bisa membaca kristal Calcite $\left(\mathrm{CaCO}_{3}\right)$ yang ada dalam semen. Sehingga nilai Calcite ini bisa dikonversi menjadi nilai LOI dengan membuat kurva kalibrasi.

Penelitian ini bertujuan untuk:

- Membuat kurva kalibrasi $\mathrm{CaCO}_{3}$ menggunakan Program XRD yang akan digunakan sebagai metode alternatif untuk pengujian secondary analisa LOI dalam semen portland tipe 1 menurut ASTM dan SNI, semen Masonry, dan semen komposit atau Portland Composite Cement (PCC).

- Efisiensi Waktu analisa.

\section{METODE PENELITIAN}

\section{Persiapan Sampel Standar}

Sampel standar yang dijadikan untuk penelitian ini yaitu semen OPC (Ordinary Portland Cement) keluaran ball mill dan Limestone sebagai variasi bahan tambahnya.
Limestone yang digunakan yaitu Limestone high grade dengan kadar $\mathrm{CaCO}_{3}$ sekitar $\pm 92 \%$ dan kadar air yang sangat rendah yaitu sekitar $\pm 0,2 \%$. Penelitian ini membuat 10 sampel standar campuran semen yang memiliki variasi kandungan Limestone filler sehingga bisa mewakili setiap jenis semen serta 1 sampel standar Limestone. Penambahan Limestone filler yang bervariasi ini dibuat dengan pencampuran menggunakan herzog mill, lalu kemudian di press menggunakan Herzog Press yang nantinya akan dikalibrasi nilai $\mathrm{CaCO}_{3}$ dalam XRD berupa pellet.

\section{Uji kadar $\mathrm{CaCO}_{3}$ pada sampel standar}

Metode ini berdasarkan ASTM C114-15 Standard Test Methods for Chemical Analysis of Hydraulic Cement di bagian nomer X2.2 merupakan modifikasi metode dari bagian 18.1.1 pada ASTM tentang penetapan $\mathrm{CO}_{2}$. Prosedur analisisnya yaitu:

1. Cawan yang sudah diketahui beratnya dan juga yang sudah berisi sampel yang sudah ditimbang dipijarkan pertama pada suhu $550^{\circ} \mathrm{C}$ selama 2 jam di dalam tanur

2. Setelah didinginkan dalam desikator dan ditimbang, cawan yang berisi sampel tersebut dipijarkan kembali pada suhu $950^{\circ} \mathrm{C}$ selama 2 jam didalam tanur

3. Terakhir, cawan yang berisi sampel tersebut didinginkan lalu ditimbang seperti langkah no. 2

4. Perbedaan LOI (hilang pijar) setelah pemijaran tersebut dianggap sebagai nilai Karbon dioksida. [2]

Untuk menentukan kadar $\mathrm{CaCO}_{3}$ dalam semen, maka rumusnya (berdasarkan ASTM C114-15, X2.2 bagian 18.1.1) adalah :

Kadar hilang pijar (LOI) $(\%)=($ Bobot yang hilang / bobot contoh ) x 100 (Persamaan 1) Kadar $\mathrm{CO}_{2}(\%)=$ LOI pada suhu $550^{\circ} \mathrm{C}-$ LOI pada suhu $950^{\circ}$ (Persamaan 2)

Kadar $\mathrm{CaCO}_{3}=$ (Massa molekul relatif $\mathrm{CaCO}_{3} /$ Massa molekul relatif $\left.\mathrm{CO}_{2}\right)$ x \%CO

(Persamaan 3)

\section{Scanning dan Kalibrasi Kurva Calcite}

Scanning dan kalibrasi kurva calcite pada XRD ini menggunakan software OXSAS. Scanning pada XRD bertujuan untuk mengetahui intensitas dari setiap kristal pada 
setiap sampel, juga untuk mendeteksi perbedaan kadar $\mathrm{CaCO}_{3}$ dalam setiap sampel. Scanning dilakukan sebelum kurva kalibrasi dibuat, karna data intensitas hasil Scanning akan digunakan dalam kalibrasi. Scanning awal dilakukan dengan percobaan sampel limestone untuk mengetahui intensitas tertinggi calcite yang ada dalam limestone beserta panjang gelombang yang sesuai untuk kalibrasi. Selanjutnya Scanning dilakukan dengan 10 sampel semen standar mengikuti panjang gelombang yang sudah diatur sebelumnya. Kurva yang dihasilkan diharapkan dapat bermanfaat sebagai metode sekunder untuk analisa calcite dalam semen.

\section{Verifikasi dan pengumpulan data}

Verifikasi data sampel standar dilakukan dengan menggunakan sampel standard semen 1887b yang sudah diketahui nilai benarnya. Sampel ini diuji kadar CaCO3 dan LOI nya untuk memastikan metode yang dikerjakan benar dan akurat, dengan cara membandingkan nilai hasil uji dengan nilai benar yang sudah diketahui. Pengumpulan data dilakukan setelah kalibrasi selesai dan telah dihasilkan kurva calcite. Setelah itu dilakukan uji coba menggunakan sampel rutin kemudian data hasil uji di kumpulkan lalu diverifikasi. Data Calcite hasil uji coba menggunakan sampel rutin diverifikasi menggunakan data hasil uji LOI metode wet analisis. Selain data Calcite, diperlukan juga data waktu sebagai parameter optimasi alat tersebut.

\section{HASIL DAN PEMBAHASAN}

\section{Persiapan Sampel Standar}

Sampel standar yang dibuat yaitu 11, terdiri dari 10 sampel semen campuran variasi limestone dan 1 sampel dry limestone. Sampel dry limestone di giling terlebih dahulu sampai dihasilkan residue $\pm 20 \%$. Sebelum limestone digiling, harus dikeringkan terlebih dahulu untuk mengurangi kandungan air, lalu dilakukan uji coba penggilingan untuk mendapatkan residu $\pm 20 \%$

Tabel. 1 Hasil uji coba penggilingan

\begin{tabular}{|c|c|c|}
\hline $\begin{array}{c}\text { Massa } \\
\text { (gr) }\end{array}$ & $\begin{array}{c}\text { Waktu Penggilingan } \\
\text { (detik) }\end{array}$ & $\begin{array}{c}\text { Residu } \\
\text { (\%) }\end{array}$ \\
\hline 51,9 & 100 & 49 \\
\hline 50,8 & 100 & 59,44 \\
\hline 50,3 & 100 & 61,43 \\
\hline 50,1 & 100 & 56,61 \\
\hline 50,9 & 100 & 59,37 \\
\hline 50,5 & 100 & 57,41 \\
\hline 50,8 & 50 & 57,48 \\
\hline 50,4 & 20 & 24,79 \\
\hline 50,2 & 10 & 21,27 \\
\hline
\end{tabular}

Dari tabel 1 maka didapatkan waktu penggilingan yang efisien yaitu 10 detik untuk sampel limestone 50 gram. Selanjutnya untuk sampel standar semen campuran dibuat menjadi 100 gram per sampelnya. Sehingga jika sesuai dengan persentase campuran semen, misal semen OPC dengan kadar variasi limestone 3\% dibuat menjadi 100 gram maka 97 gram semen OPC dan 3 gram limestone yang sudah digiling tadi.

\section{Uji Kadar $\mathrm{CaCO}_{3}$ pada sampel standar}

Sampel yang diuji dalam penelitian ini yaitu sampel standar yang telah dibuat sebelumnya. Sebanyak 10 sampel standar semen campuran dan 1 sampel dry limestone (Dry LS) yang sudah mengalami penggilingan. Berikut ini adalah hasil uji $\mathrm{CaCO}_{3}$ :

Tabel 2. Hasil penimbangan pengujian $\mathrm{CaCO}_{3}$

\begin{tabular}{|c|c|c|c|c|c|c|}
\hline & Dry LS & $\begin{array}{c}\text { OPC } \\
\text { Blanko }\end{array}$ & $\begin{array}{c}\text { OPC +3\% } \\
\text { LS }\end{array}$ & $\begin{array}{c}\text { OPC +5\% } \\
\text { LS }\end{array}$ & $\begin{array}{c}\text { OPC +10\% } \\
\text { LS }\end{array}$ & $\begin{array}{c}\text { OPC +12\% } \\
\text { LS }\end{array}$ \\
\hline $\begin{array}{c}\text { Cawan + sampel } \\
\text { (gr) }\end{array}$ & 16,9724 & 17,3283 & 171021 & 15,3573 & 18,1173 & 17,8867 \\
\hline Cawan (gr) & 15,9714 & 16,3283 & 16,103 & 14,3594 & 17,1106 & 16,8887 \\
\hline $\begin{array}{c}\text { Cawan+ residu } \\
(550) \text { (gr) }\end{array}$ & 16,9639 & 17,3226 & 17,095 & 15,3504 & 18,1111 & 17,8806 \\
\hline $\begin{array}{c}\text { Cawan+ residu } \\
(950) \text { (gr) }\end{array}$ & 16,5571 & 17,3028 & 17,0644 & 15,3118 & 18,0514 & 17,8135 \\
\hline
\end{tabular}


Sugeng Mulyono dkk., Optimasi Channel XRD....

\begin{tabular}{|c|c|c|c|c|c|}
\hline & $\begin{array}{c}\text { OPC }+15 \% \\
\text { LS }\end{array}$ & $\begin{array}{c}\text { OPC }+20 \% \\
\text { LS }\end{array}$ & $\begin{array}{c}\text { OPC }+25 \% \\
\text { LS }\end{array}$ & $\begin{array}{c}\text { OPC }+30 \% \\
\text { LS }\end{array}$ & $\begin{array}{c}\text { OPC }+40 \% \\
\text { LS }\end{array}$ \\
\hline $\begin{array}{c}\text { Cawan + sampel } \\
\text { (gr) }\end{array}$ & 18,0204 & 15,8157 & 15,6442 & 16,0724 & 16,2624 \\
\hline Cawan (gr) & 17,0231 & 14,8190 & 14,6460 & 15,0730 & 15,2691 \\
\hline $\begin{array}{c}\text { Cawan+ residu } \\
\text { (550) (gr) }\end{array}$ & 18,0132 & 15,8087 & 15,6378 & 16,0660 & 16,2551 \\
\hline $\begin{array}{l}\text { Cawan+ residu } \\
\text { (950) (gr) }\end{array}$ & 17,9352 & 15,7097 & 15,5192 & 15,9267 & 16,0778 \\
\hline
\end{tabular}

Kadar $\mathrm{CaCO}_{3}$ didapat dari perbandingan nilai molekul relatif $\mathrm{CaCO}_{3}$ dengan nilai molekul relatif $\mathrm{CO}_{2}$ dikalikan dengan persentase $\mathrm{CO}_{2}$ yang didapat. Dimana nilai $\mathrm{CO}_{2}$ merupakan selisih antara nilai LOI pada suhu $550^{\circ} \mathrm{C}$ dengan LOI pada suhu $950^{\circ} \mathrm{C}$.

Berikut perhitungannya: (sampel dry limestone sebagai contoh data perhitungan)

Kadar LOI pada suhu $550^{\circ} \mathrm{C}$ $=[\{($ cawan + sampel $)-($ cawan + residu $)\} /$ $\{($ cawan + sampel $)-($ cawan $)\}] \times 100 \%$ (Persamaan. 1) $=[\{(16,9724)-(16,9639)\} /\{(16,9724)-$ $(15,9714)\}] \times 100 \%=\mathbf{0 , 8 5 \%}$

Kadar LOI pada suhu $950^{\circ} \mathrm{C}$ : $=[\{($ cawan + sampel $)-($ cawan + residu $)\} /$ $\{($ cawan + sampel $)-($ cawan $)\}] \times 100 \%$ (Persamaan. 1)
$=[\{(16,9724)-(16,5571)\} /\{(16,9724)-$ $(15,9714)\}] \times 100 \%=\mathbf{4 1 , 4 9 \%}$

Kadar $\mathrm{CO}_{2}(\%)$ :

$=$ LOI pada suhu $550^{\circ} \mathrm{C}-$ LOI pada suhu $950^{\circ} \mathrm{C}$

(Persamaan. 2)

$=41,49 \%-0,85 \%$

$=40,64 \%$

Kadar $\mathrm{CaCO}_{3}$ :

$=\left(\right.$ Massa molekul relatif $\mathrm{CaCO}_{3} /$ Massa molekul relatif $\left.\mathrm{CO}_{2}\right) \times \% \mathrm{CO}_{2}$

(Persamaan. 3)

$=(100 / 44) \times 40,64 \%=\mathbf{9 2 , 3 6} \%$

Sehingga didapat Kadar $\mathrm{CaCO}_{3}$ dari seluruh sampel yaitu :

Tabel 3. Hasil perhitungan mencari kadar $\mathrm{CaCO}_{3}$

\begin{tabular}{|c|c|c|c|c|}
\hline Nama Sampel & $\mathrm{LOI} 550^{\circ} \mathrm{C}(\%)$ & $\mathrm{LOI} 950^{\circ} \mathrm{C}(\%)$ & $\mathrm{CO}_{2}(\%)$ & $\mathrm{CaCO}_{3}(\%)$ \\
\hline Dry Limestone & 0,85 & 41,49 & 40,64 & 92,36 \\
\hline OPC Blanko & 0,57 & 2,55 & 1,98 & 4,50 \\
\hline OPC+3\%LS & 0,71 & 3,77 & 3,06 & 6,95 \\
\hline OPC+5\%LS & 0,69 & 4,56 & 3,87 & 8,80 \\
\hline OPC+10\%LS & 0,62 & 6,55 & 5,93 & 13,48 \\
\hline OPC+12\%LS & 0,61 & 7,33 & 6,72 & 15,27 \\
\hline OPC+15\%LS & 0,72 & 8,54 & 7,82 & 17,77 \\
\hline OPC+20\%LS & 0,70 & 10,64 & 9,94 & 22,59 \\
\hline OPC+25\%LS & 0,64 & 12,52 & 11,88 & 27,00 \\
\hline OPC+30\%LS & 0,64 & 14,58 & 13,94 & 31,68 \\
\hline OPC+40\%LS & 0,73 & 18,58 & 17,85 & 40,57 \\
\hline
\end{tabular}

Pada Tabel. 3 terlihat bahwa kadar $\mathrm{CaCO}_{3}$ tertinggi ada dalam Limestone yaitu 92,36\%. Kadar $\mathrm{CaCO}_{3}$ dalam sampel lain juga sesuai dengan persentase variasi limestone yang ditambahkan. Untuk memastikan kadar tersebut benar sesuai dengan persentasi campuran semen dengan limestone dalam setiap sampel, maka dilakukan perhitungan LOI Simulasi, yaitu dengan mengalikan persentase material dengan LOI limestone dan semen blanko pada suhu $950^{\circ} \mathrm{C}$. 
Tabel 4. Hasil perhitungan LOI simulasi

\begin{tabular}{|l|c|c|c|c|c|c|c|c|c|}
\hline \multicolumn{1}{|c|}{ LOI Simulasi } & $\begin{array}{c}\text { OPC } \\
+\end{array}$ & $\begin{array}{c}\text { OPC } \\
+\end{array}$ & $\begin{array}{c}\text { OPC } \\
+\end{array}$ & $\begin{array}{c}\text { OPC } \\
+\end{array}$ & $\begin{array}{c}\text { OPC } \\
+\end{array}$ & $\begin{array}{c}\text { OPC } \\
+\end{array}$ & $\begin{array}{c}\text { OPC } \\
+\end{array}$ & $\begin{array}{c}\text { OPC } \\
+\end{array}$ & $\begin{array}{c}\text { OPC } \\
+\end{array}$ \\
\hline LOI Semen & 2,47 & 2,42 & 2,29 & 2,24 & 2,17 & 2,04 & 1,91 & 1,78 & 1,53 \\
\hline LOI LS & 1,24 & 2,07 & 4,15 & 4,98 & 6,22 & 8,30 & 10,37 & 12,45 & 16,60 \\
\hline LOI Semen Mix & 3,72 & 4,50 & 6,44 & 7,22 & 8,39 & 10,34 & 12,28 & 14,23 & 18,13 \\
\hline LOI Hasil Uji & 3,77 & 4,56 & 6,55 & 7,33 & 8,54 & 10,64 & 12,52 & 14,58 & 18,58 \\
\hline
\end{tabular}

Perhitungan LOI Simulasi:

LOI semen $=$ persentase semen dalam sampel x LOI semen blanko pada suhu $950^{\circ} \mathrm{C}$ (Persamaan. 1a)

LOI LS = persentase limestone dalam sampel $\mathrm{x}$ LOI limestone pada suhu $950^{\circ} \mathrm{C}$ (Persamaan. 2a)

LOI Semen Mix = LOI semen + LOI LS

(Persamaan. 3a)

Contoh Perhitungan (sampel OPC $+3 \%$ LS sebagai data contoh):

LOI semen=97\% $\quad=2,55=2,47 \%$

(Persamaan. 1a)

LOI LS $=3 \% \times 41,49$

$1,24 \%$

(Persamaan. 2a)

LOI Semen Mix $=2,47 \%+1,24 \%=3,72$ $\%$

(Persamaan. 3a)
Jika dilihat dari Tabel. 4 LOI hasil uji OPC $+3 \%$ LS adalah 3,77 \% sedangkan nilai LOI simulasinya adalah $3,72 \%$, sehingga bisa dinyatakan bahwa campuran sampel benar karena nilai hasil uji LOI sesuai dengan prediksi.

Untuk memastikan pengujian tersebut benar, maka dilakukan pengujian kembali menggunakan sampel standard SRM (Standard Reference Material) 1887b yang sudah diketahui nilai LOI dan $\mathrm{CO}_{2}$ dengan nilai benar LOI Total atau LOI pada suhu $950^{\circ} \mathrm{C}$ yaitu $2,12 \%$ dengan toleransi sebesar $\pm 0,027$ dan nilai benar LOI dari suhu $550^{\circ} \mathrm{C}$ ke suhu $950^{\circ} \mathrm{C}$ atau sama dengan nilai $\mathrm{CO}_{2}$ yaitu $0,89 \%$ dengan toleransi sebesar $\pm 0,14$. [3]

Tabel 5. Hasil pengujian SRM 1887b

\begin{tabular}{|c|c|c|c|c|}
\hline SRM 1887b & Nilai Hasil Uji & Batas Max & Nilai Referensi & Batas Min \\
\hline Cawan+sampel (gr) & 17,1096 & & & \\
\hline Cawan (gr) & 16,1026 & & & \\
\hline Cawan+residu (550) (gr) & 17,0967 & & & \\
\hline Cawan+residu (950) (gr) & 17,0882 & & & \\
\hline LOI $550^{\circ} \mathrm{C}(\%)$ & 1,28 & & & \\
\hline LOI $950^{\circ} \mathrm{C}(\%)$ & 2,13 & 2,15 & 2,12 & 2,09 \\
\hline $\mathrm{CO}_{2}(\%)$ & 0,84 & 1,03 & 0,89 & 0,75 \\
\hline
\end{tabular}

Dari Tabel. 5 dapat dilihat bahwa hasil pengujian $\mathrm{CO}_{2}$ dan LOI pada suhu $950^{\circ} \mathrm{C}$ pada sampel SRM 1887b masih dalam range yang disyaratkan dalam referensi. Sehingga dapat disimpulkan bahwa metode pengujian yang dilakukan benar.

\section{Scanning dan Kalibrasi Kurva Calcite}

Scanning dilakukan terhadap 10 sampel standar semen dan 1 sampel standar dry limestone. Berikut ini adalah hasil Scanning 11 sampel tersebut. 


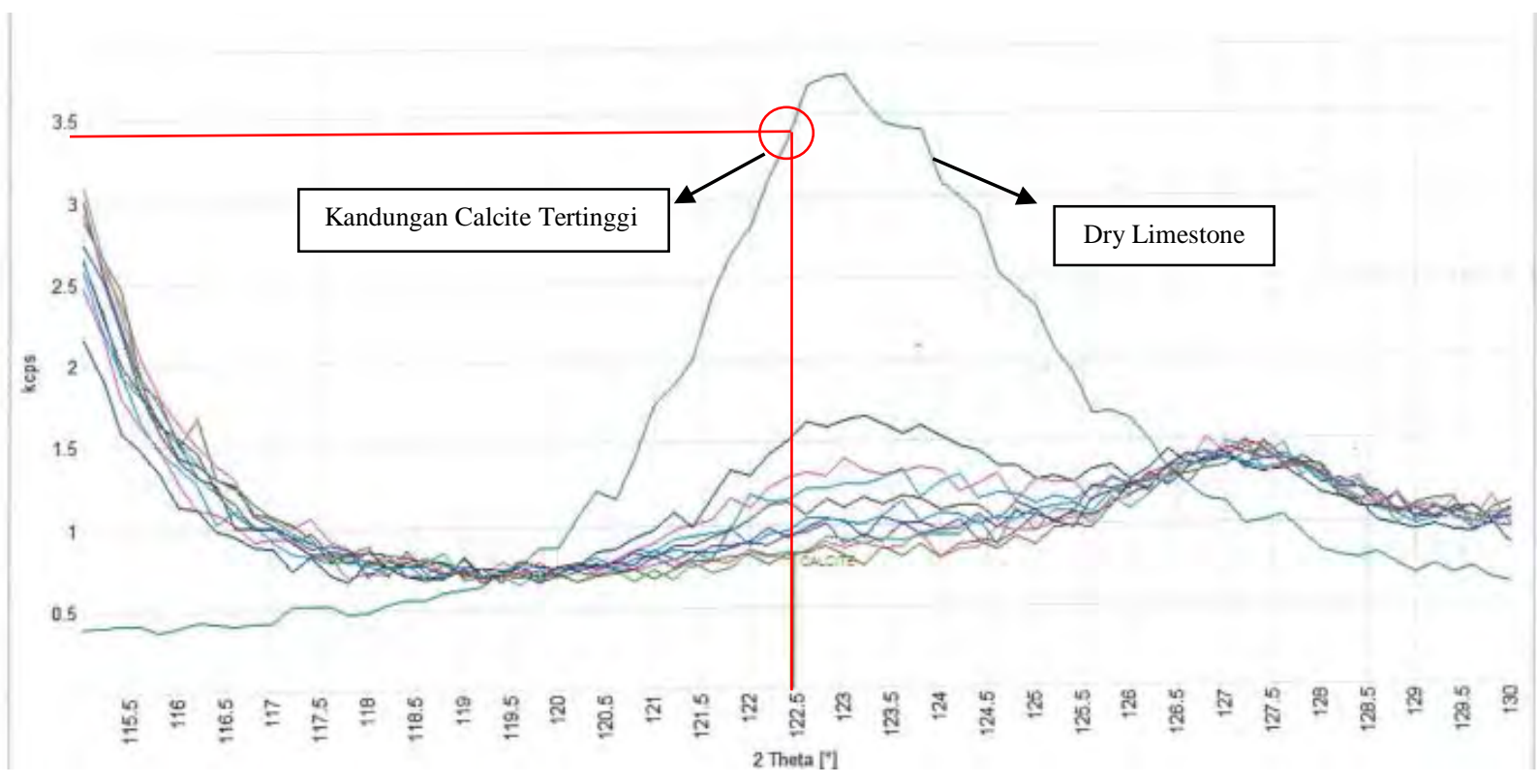

Gambar 1. Kurva Scanning 11 sampel standar

Berdasarkan kurva Gambar. 1 XRD membaca intensitas tertinggi dan terendah sampel. Dari kurva tersebut dijelaskan bahwa intensitas tertinggi terdapat pada limestone. Karena limestone memiliki kandungan calcite yang lebih tinggi daripada sampel yang lain. Calcite dalam limestone ini berada pada panjang gelombang $122,5^{\circ}$. Sehingga jika ditarik garis lurus antara panjang gelombang dengan intensitas, limestone memiliki intensitas sebesar 3,4828344 kcps. Sedangkan untuk sampel standar yang lain memiliki intensitas lebih rendah dibanding limestone, karena kandungan calcitenya lebih sedikit dibandingkan dengan limestone. Semakin rendah kandungan calcite semakin rendah pula intensitas yang terbaca. Dari kurva tersebut juga digambarkan bahwa semakin rendah intensitasnya semakin tidak terlihat perbedaan yang signifikan, ini diakibatkan oleh efek penggilingan ketika membuat pellet, sehingga kristal yang ada dalam sampel mengalami kerusakan. Intensitas pada setiap sampel bisa dilihat dalam Tabel. 6 .

Tabel. 6 Intensitas Sampel standar

\begin{tabular}{|l|l|}
\hline Nama Sampel & Intensitas (Kcps) \\
\hline Dry Limestone & 3,4828344 \\
\hline OPC Blanko & 0,8018668 \\
\hline OPC+3\%LS & 0,8460174 \\
\hline OPC+5\%LS & 0,8755349 \\
\hline OPC+10\%LS & 0,9461083 \\
\hline OPC+12\%LS & 0,9971043 \\
\hline OPC+15\%LS & 1,0392104 \\
\hline OPC+20\%LS & 1,1164320 \\
\hline OPC+25\%LS & 1,2225280 \\
\hline OPC+30\%LS & 1,3151408 \\
\hline OPC+40\%LS & 1,5469879 \\
\hline
\end{tabular}

Setelah data intensitas dihasilkan, data tersebut dimasukan kedalam program kalibrasi beserta dengan data $\mathrm{CaCO}_{3}$ setiap sampel yang sudah dihitung (lihat Tabel. 3). Sumbu x merupakan data konsentrasi, dalam kasus ini yaitu data $\mathrm{CaCO} 3$, sedangkan sumbu y merupakan data intensitas dalam Kcps. Sehingga di dapatkan kurva kalibrasi sebagai berikut. 


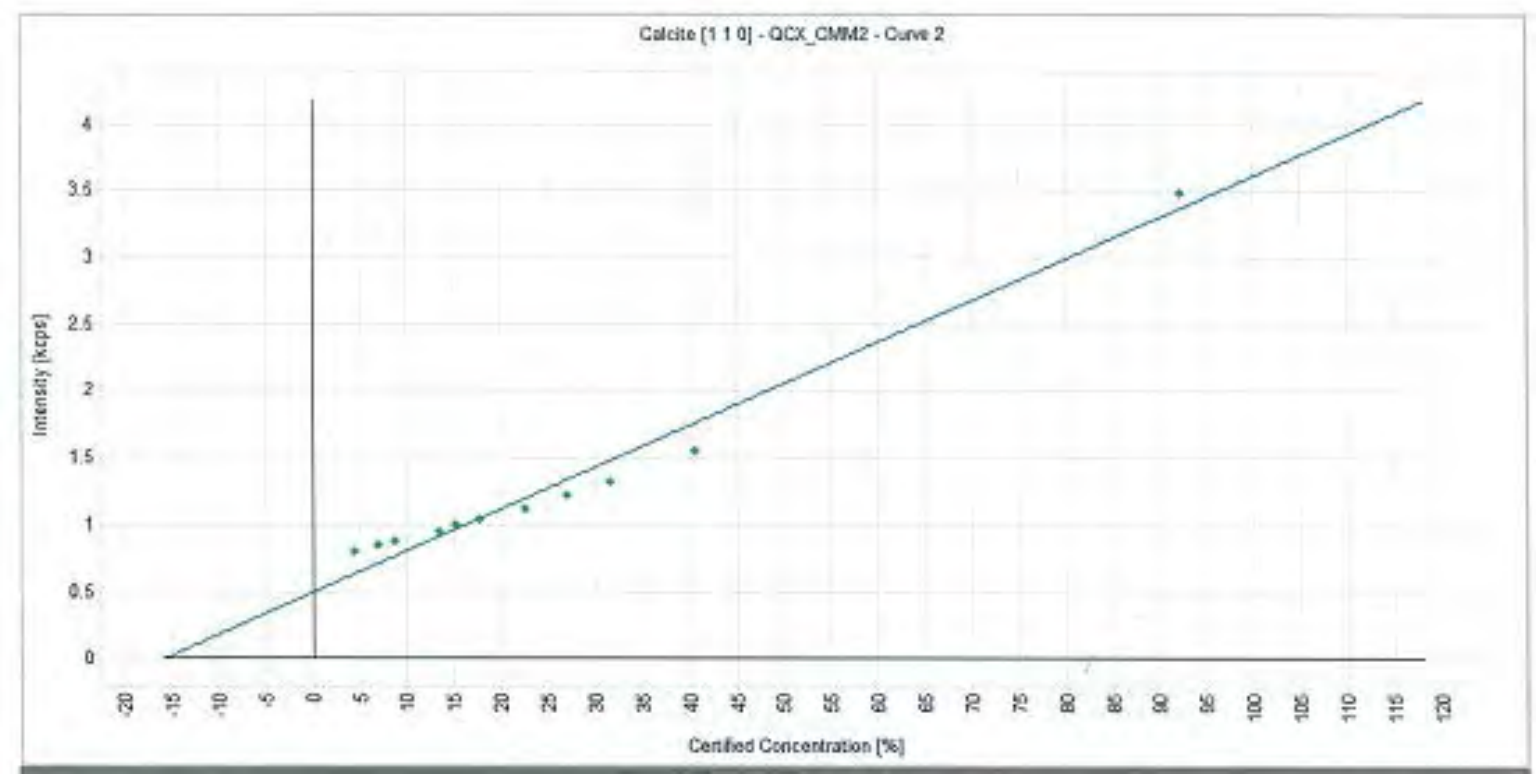

Gambar 2. Kurva Kalibrasi calcite

Berdasarkan gambar 2 terlihat bahwa kurva tersebut tidak linear, dari program kalibrasi tersebut didapatkan regresi sebesar 0,972480, dimana kurva tersebut belum sepenuhnya akurat karena regresi yang diharapkan yaitu mendekati angka 1. Sehingga penelitian ini mencoba untuk mengecualikan salah satu sampel yang memiliki intensitas tetinggi sehinga kurva kalibrasi yang didapat seperti pada gambar. 3

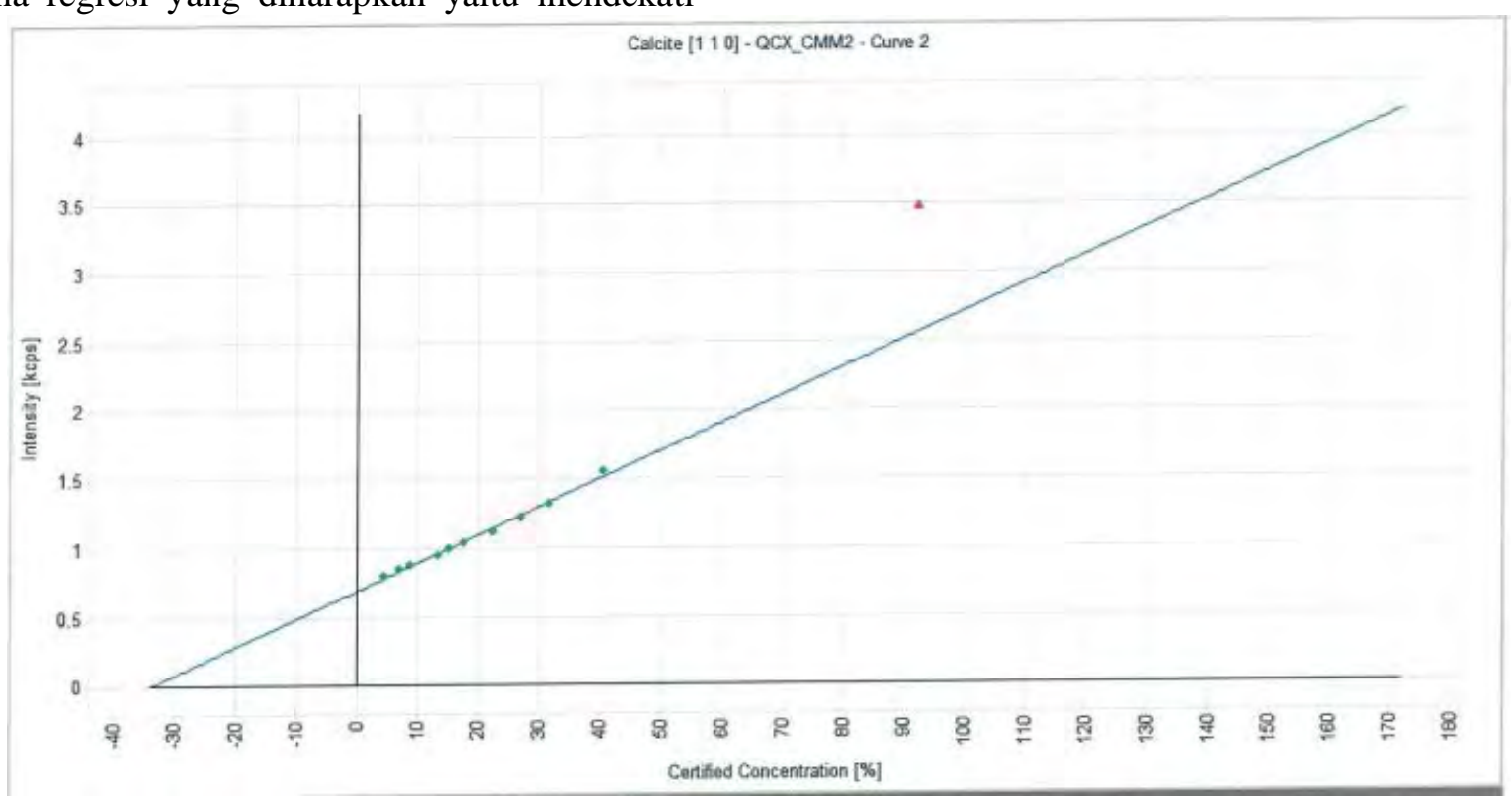

Gambar 3. Kurva kalibrasi calcite setelah pengecualian

Setelah pengecualian, terlihat pada gambar. 3 bahwa kurva tersebut linear dan mendapatkan regresi sebesar 0,992398, dimana angka tersebut

\section{Hasil uji sampel rutin dan perhitungan waktu}

Untuk data perhitungan waktu diambil 15 sampel semen lebih mendekati angka 1 dibandingkan dengan regresi

Tabel 7. Waktu pengerjaan LOI

\begin{tabular}{|l|c|c|}
\hline No & Sampel & Waktu pengerjaan \\
\hline
\end{tabular}


POLITEKNOLOGI VOL. 17 NO. 3, SEPTEMBER 2018

\begin{tabular}{|c|c|c|c|c|}
\hline & & LOI Wet & LOI XRD & sell \\
\hline 1 & nen $\mathrm{A}$ & $2 \cdot 17 \cdot 56$ & 0:07:36 & $2: 10: 20$ \\
\hline 2 & & & & $: 10: 33$ \\
\hline 3 & & 3 & 7:20 & $: 10: 13$ \\
\hline 4 & Sem & $2: 17$ & 53 & 2:10:16 \\
\hline 5 & Semen E & $2: 3$ & $: 29$ & $2: 28: 10$ \\
\hline 6 & & & & 33 \\
\hline 7 & Sem & $2: 3$ & :13 & $2: 26: 57$ \\
\hline 8 & Semen $\mathrm{H}$ & 2:34:44 & 7:27 & $2: 27: 17$ \\
\hline 9 & $\mathrm{I}$ & $2: 3$ & 0:08:16 & $2: 26: 55$ \\
\hline 10 & & & & $2: 27: 31$ \\
\hline 11 & & & & $2: 20: 19$ \\
\hline 12 & Sem & $2: 2$ & :38 & 2:19:51 \\
\hline 13 & Semen M & & & $2: 20: 12$ \\
\hline 14 & & & & 2:19:52 \\
\hline 15 & Semen $\mathrm{O}$ & $2: 27: 11$ & 0:07:23 & 2:19:48 \\
\hline \multicolumn{2}{|c|}{ Rata rata } & $2: 27: 57$ & 0:07:34 & $2: 20: 23$ \\
\hline
\end{tabular}

Dari tabel. 7 bisa dilihat bahwa waktu pengerjaan Analisa LOI menggunakan XRD lebih efisien dibandingkan dengan waktu pengerjaan LOI Metode wet. Secara keseluruhan,Pengerjaan LOI bisa menghemat waktu sebanyak 2 jam 20 menit 23 detik.

Sampel rutin yang di uji yaitu semen masonry, semen PCC, dan semen OPC tipe ASTM dan SNI.

Tabel 8. Hasil Uji coba sampel semen

\begin{tabular}{|l|l|l|c|c|c|c|}
\hline No & Jenis Semen & \multicolumn{1}{|c|}{ Type } & $\begin{array}{c}\text { LOI Wet } \\
(\%)\end{array}$ & $\begin{array}{c}\text { CaCO3 (new curve) } \\
\%\end{array}$ & $\begin{array}{c}\text { LOI Konversi } \\
(\%)\end{array}$ & $\begin{array}{c}\text { Selisih } \\
(\%)\end{array}$ \\
\hline 1 & Semen Masonry & SNI 15-3758 & 13,5 & 25,01 & 11,00 & 2,50 \\
\hline 2 & Semen Masonry & SNI 15-3759 & 13,31 & 24,73 & 10,88 & 2,43 \\
\hline 3 & Semen PCC & ASTM 1157 GU & 11,1 & 22,1 & 9,72 & 1,38 \\
\hline 4 & Semen PCC & ASTM 1157 GU & 11,5 & 23,18 & 10,20 & 1,30 \\
\hline 5 & Semen PCC & ASTM 1157 GU & 11,1 & 23,03 & 10,13 & 0,97 \\
\hline 6 & Semen PCC & ASTM 1157 GU & 11,2 & 22,99 & 10,12 & 1,08 \\
\hline 7 & Semen PCC & ASTM 1157 GU & 11,13 & 22,44 & 9,87 & 1,26 \\
\hline 8 & Semen PCC & ASTM 1157 GU & 11,2 & 22,37 & 9,84 & 1,36 \\
\hline 9 & Semen PCC & ASTM 1157 GU & 11,5 & 23,78 & 10,46 & 1,04 \\
\hline 10 & Semen PCC & ASTM 1157 GU & 11,2 & 22,33 & 9,83 & 1,37 \\
\hline 11 & Semen PCC & ASTM 1157 GU & 11,09 & 22,16 & 9,75 & 1,34 \\
\hline 12 & Semen PCC & ASTM 1157 GU & 11,38 & 24,56 & 10,81 & 0,57 \\
\hline 13 & Semen OPC & ASTM C150 I & 2,3 & 4,75 & 2,09 & 0,21 \\
\hline 14 & Semen OPC & ASTM C150 I & 2,1 & 4,87 & 2,14 & $-0,04$ \\
\hline 15 & Semen OPC & ASTM C150 I & 2,1 & 5,24 & 2,31 & $-0,21$ \\
\hline 16 & Semen OPC & ASTM C150 I & 2,1 & 6,50 & 2,86 & $-0,76$ \\
\hline 17 & Semen OPC & ASTM C150 I & 2 & 5,48 & 2,41 & $-0,41$ \\
\hline 18 & Semen OPC & ASTM C150 I & 2,3 & 5,21 & 2,29 & 0,01 \\
\hline 19 & Semen OPC & ASTM C150 I & 2,33 & 4,94 & 2,17 & 0,16 \\
\hline 20 & Semen OPC & ASTM C150 I & 2,33 & 5,57 & 2,45 & $-0,12$ \\
\hline 21 & Semen OPC & ASTM C150 I & 2,3 & 5,83 & 2,57 & $-0,27$ \\
\hline
\end{tabular}


Sugeng Mulyono dkk., Optimasi Channel XRD....

\begin{tabular}{|l|l|l|c|c|c|c|}
\hline 22 & Semen OPC & SNI TIPE I & 3,42 & 6,66 & 2,93 & 0,49 \\
\hline 23 & Semen OPC & SNI TIPE I & 3,6 & 7,53 & 3,31 & 0,29 \\
\hline 24 & Semen OPC & SNI TIPE I & 3,3 & 7,55 & 3,32 & $-0,02$ \\
\hline 25 & Semen OPC & SNI TIPE I & 3,6 & 6,74 & 2,97 & 0,63 \\
\hline 26 & Semen OPC & SNI TIPE I & 3,5 & 7,91 & 3,48 & 0,02 \\
\hline 27 & Semen OPC & SNI TIPE I & 3,6 & 7,83 & 3,45 & 0,15 \\
\hline 28 & Semen OPC & SNI TIPE I & 3,7 & 7,44 & 3,27 & 0,43 \\
\hline 29 & Semen OPC & SNI TIPE I & 4 & 7,96 & 3,50 & 0,50 \\
\hline 30 & Semen OPC & SNI TIPE I & 3,34 & 6,36 & 2,80 & 0,54 \\
\hline
\end{tabular}

Berdasarkan Tabel. 8 dijelaskan bahwa untuk jenis semen masonry dan dan semen PCC belum akurat, karena selisih perbedaannya masih lebih dari $0,5 \%$, sedangkan untuk jenis semen OPC cenderung akurat karna hanya terdapat 4 sampel saja yang memiliki selisih lebih dari 0,5\%. Berdasarkan tabel 6, terdapat nilai 14 sampel yang mendekati nilai wet dari 30 sampel, Secara keseluruhan, akurasi kurva calcite yaitu sebesar :

$$
=(14 / 30) \times 100 \%=46,67 \%
$$

Tetapi jika untuk semen OPC saja, terdapat 14 sampel yang mendekati nilai wet dari 18 sampel semen OPC, maka ke akurasian kurva tersebut sebesar:

$=(14 / 18) \times 100 \% \quad=77,78 \%$

\section{KESIMPULAN}

Hasil penelitian ini disimpulkan bahwa waktu analisa LOI XRD lebih cepat dibandingkan LOI metode wet, dari waktu 2 jam 27 menit 57 detik menjadi 7 menit 34 detik, artinya bisa menghemat waktu sebanyak 2 jam 20 menit 23 detik. Akurasi kurva secara keseluruhan sebesar 46,67 \%, tetapi untuk akurasi semen OPC sebesar 77,78\%, akurasi kurva tersebut bisa diatasi dengan cara modifikasi parameter xray atau modifikasi preparasi sampel.

\section{UCAPAN TERIMAKASIH}

Terimakasih kepada departemen Laboratorium Technical PT Holcim Indonesia yang telah memberi kesempatan dan fasilitas sehingga penelitian dapat dilaksanakan..

\section{DAFTAR PUSTAKA}

[1] Rudianto, "TEMPAT BERBAGI ILMU,HILANG PIJAR," 6102010. [Online]. Available: https://rdianto.wordpress.com/2010/10/06 hilang-pijar/.

[2] "Standard Test Method for Chemical Analysis of Hydraulic Cement". United States Patent C114-15, 15 April 2015.

[3] C. A. Gonzales dan R. L. Watters, "Certificate of Analysis, Standard Reference Materials 1887b”. Paten MD 20899, 17 December 2013. 
Sugeng Mulyono dkk., Optimasi Channel XRD.... 